\title{
Middle Jurassic coccolith fluxes: a novel approach by automated quantification
}

\author{
Baptiste Suchéras-Marx ${ }^{1,2,3}$ *, Fabienne Giraud ${ }^{4}$, Emanuela Mattioli ${ }^{1}$, Yves Gally ${ }^{5}$, Nicolas \\ Barbarin $^{5}$, Luc Beaufort ${ }^{5}$ \\ ${ }^{1}$ UMR CNRS 5276 LGL-TPE, Université Claude Bernard Lyon 1, Ecole Normale Supérieure \\ Lyon, Campus de la DOUA, Bâtiment Géode, 69622 Villeurbanne Cedex, France \\ ${ }^{2}$ Uppsala University, Department of Earth Sciences, Palaeobiology, Villavägen 16, SE-752 \\ 36 Uppsala, Sweden \\ ${ }^{3}$ Université de Lyon, Université Jean Monnet and UMR-CNRS 6524, Laboratoire Magmas et \\ Volcans, 23 rue du Dr Paul Michelon, 42023 Saint Etienne, France \\ ${ }^{4}$ ISTerre, UMR 5275, Université de Grenoble 1, 1381 rue de la piscine, BP 53, 38041 \\ Grenoble Cedex 9, France \\ ${ }^{5}$ CEREGE, UMR CNRS 6635, Université Aix-Marseille, Europôle Méditerranéen de l'Arbois \\ BP 80, 13545 Aix-en-Provence Cedex 04, France \\ * Corresponding author email: baptiste.sucheras@gmail.com
}

Keywords: Aalenian-Bajocian; SYRACO system; coccolith absolute abundance and flux; coccolith production; Lusitanian Basin; French Subalpine Basin

\begin{abstract}
Coccolithophores, major pelagic carbonate producers, underwent important changes during the latest Aalenian-Early Bajocian (ca.-170 Ma, Middle Jurassic). Specifically, a new genus called Watznaueria diversified and started dominating the coccolith assemblages. While this change in the coccolith assemblages is already known, the impact on coccolith absolute abundances and fluxes is still misunderstood. Here we tested for the first time on Mesozoic deposits an automated counting method using the SYRACO system, and then compared these results with a classic counting method. Two neural networks were created based on the shape, birefringence and size of coccoliths, the first of which contained only one class and the second of which was composed of six classes. Based on the morphological criteria used for the neural networks, coccoliths were not identified at the species level. We quantified coccolith absolute abundances and estimated fluxes for the latest Aalenian-Early Bajocian in two well-dated and correlated sections, Cabo Mondego in Portugal and Chaudon-Norante in France. There is a strong linear correlation between classic and automatic counting $(r>0.8)$ supporting automatic counting as a reliable method for coccolith absolute abundance and flux quantification. In spite of under- or over-estimation by automatic counting with respect to classic counting, the absolute abundance stratigraphic trends are remarkably similar. Underor over-estimation may be reduced by further technical improvements such as automatic focus. At Cabo Mondego, coccolith fluxes increased from $0.2 \times 10^{9}$ coccoliths $/ \mathrm{m}^{2} / \mathrm{yr}$ in the latest Aalenian to $700 \times 10^{9}$ coccoliths $/ \mathrm{m}^{2} / \mathrm{yr}$ in the middle of the Laeviuscula ammonite Zone (Early Bajocian), remaining high for the rest of the Early Bajocian. At Chaudon-Norante, a similar trend was observed. This coccolith flux increase is therefore considered to be a supra-

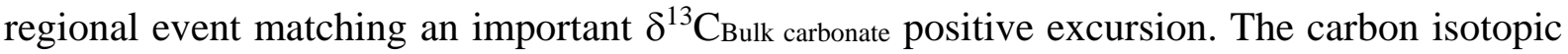
positive excursion, along with the onset of radiolarian sedimentation and coccolith fluxes is related to a gradual increase in the fertility of the oceans during the Early Bajocian and is likely associated with warmer and more humid climates and associated enhanced continental weathering.
\end{abstract}




\section{Introduction}

Coccoliths are microscopic calcite platelets produced by planktonic algae called coccolithophores. They constitute about one half of the pelagic carbonate production in modern oceans and significantly contribute to the carbon cycle (Westbroek et al., 1993). Coccolithophores first appeared in the fossil record at the end of the Triassic ( 210 Ma ago; Prins, 1967), and gradually colonized the open ocean during the Jurassic and Cretaceous (Roth, 1989; Hay, 2004; Erba, 2006). The impact of nannoplankton-derived carbonates on the carbonate budget of the Mesozoic ocean is highly debated. Some authors have proposed a significant increase in pelagic carbonate production during the Late Jurassic (Roth, 1989; Hay, 2004; Erba, 2006). However, mass accumulation of nannofossil-derived carbonate in Jurassic and Lower Cretaceous successions remain generally lower than the carbonate produced in shallow-water environments and exported basinwards (Mattioli and Pittet, 2002; Suan et al., 2008; Gréselle et al., 2011; Suchéras-Marx et al., 2012).

During the Early Bajocian ( -170 Ma, Middle Jurassic), the Watznaueria genus diversified and started dominating coccolith assemblages until the end of the Early Cretaceous (Cobianchi et al., 1992; Mattioli and Erba, 1999; Lees et al., 2005; Erba, 2006). This great change in the composition of coccolith assemblages is well documented (Cobianchi et al., 1992; Mattioli and Erba, 1999; Bown, 2005), but no studies have yet quantified the coccolith absolute abundance variation in relation to this diversification. Unfortunately, such quantifications are extremely time consuming and difficult to perform.

Dollfus and Beaufort (1999) and Beaufort and Dollfus (2004) developed an automated system that greatly reduces the time spent collecting data. They coupled a system of automated microscopy with a system of automatic coccolith identification called SYRACO (SYstème de Reconnaissance Automatique des COccolithes). This system has been successfully used for the quantification of coccoliths from living and recent coccolithophores (Beaufort et al., 2008; Beaufort et al., 2011). In this study, we have tested and applied the SYRACO automatic counting for coccolith flux quantification for the first time in Mesozoic deposits. This study was conducted on the latest Aalenian-Early Bajocian interval for two sites: Cabo Mondego, Portugal and Chaudon-Norante, France. The results of coccolith automated optical quantification were compared with estimates from identifications made by classical optical methods in order to test the application of automated quantification to Mesozoic deposits. Coccolith absolute abundances and fluxes are discussed in regard to other paleoenvironmental proxies, such as carbon stable isotopes.

\section{Geological settings}

\subsection{Cabo Mondego}

The Cabo Mondego section is located on the western Atlantic coast of Portugal near Figueira da Foz (Fig. 1). This section is in the Lusitanian Basin, and is bounded eastward by the Iberica Meseta. The sedimentary succession is represented by marine deposits of Late Toarcian to Kimmeridgian age (Ruget-Perrot, 1961). Cabo Mondego is the Global Stratotype Section and Point (GSSP) for the Aalenian/Bajocian boundary (Pavia and Enay, 1997) as well as the Auxiliary Stratotype Section and Point (ASSP) for the Bajocian/Bathonian boundary (Fernandez-Lopez et al., 2009). Numerous ammonites have been collected throughout the succession, allowing for the establishment of a precise biostratigraphical framework (Fernandez-Lopez et al., 1988; Henriques et al., 1994).

The studied part of the Cabo Mondego section extends from the latest Aalenian (Concavum ammonite Zone) to the end of the Early Bajocian (base of the Humphriesianum ammonite Zone; Fig. 2), which is divided into four ammonite zones: Discites, Laeviuscula, Sauzei (equivalent of the Propinquans Zone of other regions), and Humphriesianum. The succession consists of alternating marlstone and limestone and the carbonate fraction is exclusively 
micritic or microsparitic calcite (Henriques et al., 1994). The sediments corresponding to the Concavum (ca. 5.5 meters thick) and Discites (ca. 7.2 meters thick) zones are characterized by irregular nodular beds, but fairly regular alternations of ca. $20 \mathrm{~cm}$ argillaceous limestone and marlstone beds. The interval corresponding to the base of the Laeviuscula Zone (ca. $36 \mathrm{~m}$ thick) is limestone-dominated. At the base of the Sauzei Zone (ca. $32 \mathrm{~m}$ thick), the argillaceous limestone beds become more regular and thicker in comparison to the base of the section through the Humphriesianum (ca. $7 \mathrm{~m}$ ) Zone. From the Sauzei Zone, the succession becomes limestone-dominated (Ruget-Perrot, 1961; Suchéras-Marx et al., 2012).

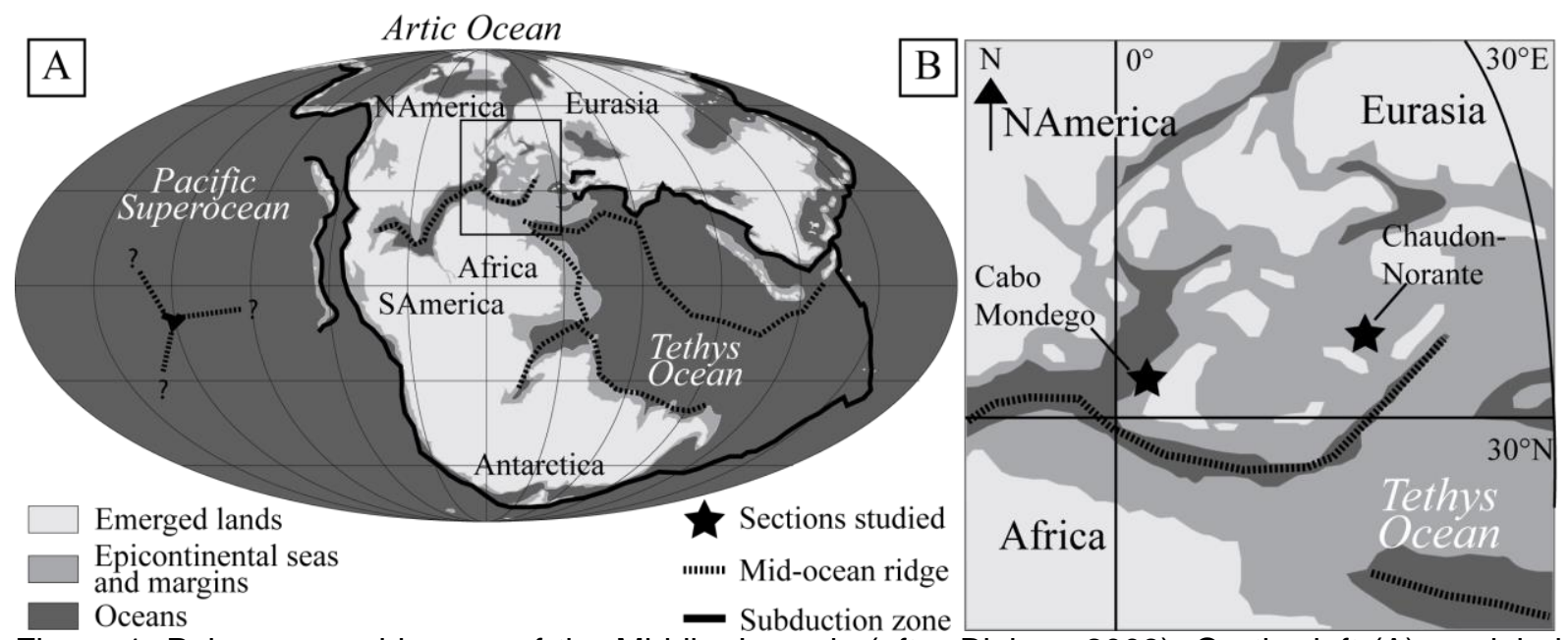

Figure 1: Paleogeographic map of the Middle Jurassic (after Blakey, 2008). On the left (A), a global view with subduction zones and mid-ocean ridges; and on the right $(B)$, a focus on the western Tethys with the location of the Cabo Mondego section in the Lusitanian Basin.

\subsection{Chaudon-Norante}

The Chaudon-Norante section, located in the Ravin de Coueste in the Digne tectonic Nappe (Southern Alps) and emplaced during the Mio-Pliocene (Lemoine, 1973; Gidon and Pairis, 1992), presents a continuous succession from the Toarcian (Early Jurassic) to the base of the Bathonian (Middle Jurassic). This section belongs to the French Subalpine Basin, which was bounded northward by the Jura platform, westward by the Central Massif and the Ardèche platform, and southward by the Provence platform (Fig. 1). This section was proposed for the Aalenian/Bajocian GSSP (Erba and Pavia, 1990). The Chaudon-Norante succession is wellexposed and the ammonite and nannofossil biostratigraphy for the Bajocian have high temporal resolution (Erba, 1990; Pavia, 1973, 1983).

The studied interval spans the end of the Aalenian to the end of the Early Bajocian, and is represented by decimeter hemipelagic marlstone/limestone alternations (Fig.3). The limestones are mainly wackestones to packstones with some bioclastic remains of Bositra (Bivalvia), radiolarians, rare benthic foraminifera and rare siliceous sponge spicules (Pavia, 1983). The end-Aalenian is dated to the upper part of the Concavum Zone and is represented by a 39.6 meter-thick section of fairly regular marlstone-limestone alternations, except for the uppermost part, which is marl-dominated. The 129 meter-thick Early Bajocian succession corresponds to four ammonite zones. The Discites Zone at the base is dominated by marlstones, and the Laeviuscula Zone displays regular marlstone-limestone alternations. The Sauzei Zone is limestone-dominated, while the Humphriesianum Zone displays regular marlstone-limestone alternations (Pavia, 1983; Suchéras-Marx et al., 2013). 


\section{Material and methods}

\subsection{Slide preparation}

Samples were prepared following the random settling method for absolute abundance quantification described by Beaufort (1991) and modified by Geisen et al. (1999). This method was used to produce homogeneous slides, and absolute abundance was estimated from the number of coccoliths found per field of view. Thus, the estimations require counting a reasonable number of fields of view rather than a fixed number of coccoliths. Two different sample preparations were made. The preparation for classic counting was made with $20 \mathrm{mg}$ to $30 \mathrm{mg}$ of powdered rock while preparation for automatic counting was made with $5 \mathrm{mg}$ to 8 $\mathrm{mg}$ of powdered rock. We used less material for automatic counting in order to have the wellspaced coccolith arrangement necessary for a proper recognition by SYRACO.

\subsection{Classic counting}

The term "classic" is used here for manually performed, non-automatic counting. Forty samples were studied from Cabo Mondego and 50 from Chaudon-Norante. We used a Zeiss Axioskop 40 optical microscope, under polarized light conditions, at a magnification of x1000. Usually, 300 coccoliths per slide were counted but, when nannofossils were really scarce, at least 100 fields of view or 100 specimens were counted per slide. A preservation index was estimated for each sample, taking into account etching and overgrowth, as described by Roth (1983). Three states of coccolith preservation are described; "Poor", "Moderate" and "Good". "Poor" corresponds to the loss of central area features and the presence of overgrowth; "Moderate" signifies partial loss of central area features and minor to absent overgrowth or etching; "Good" corresponds to preservation of central area features and an absence of overgrowth or etching. Coccolith preservation was estimated only in classically counted samples; the images in automatically counted samples were not of sufficient quality to estimate preservations.

\subsection{Automatic counting}

We examined 78 samples from Cabo Mondego and 113 samples from Chaudon-Norante. The automated system consists of a Leica DM 2000 optical microscope linked to a Spot Flex Monochromatic 15.0 64 Mpx camera and a Märkhäuser mechanical device, which can be moved manually by a joystick or automatically using the Labview software. For each sample, pictures were taken by focusing on the foremost and last fields of view of the surface of the slide to be analyzed, so that a predictable focus was established by the system in all other fields of view. 1100 pictures (picture size $2048 \times 2048$ pixels; 1 pixel $=0.073 \mu \mathrm{m}$ ) were taken per slide, but a variable number of blurred photographs occurred for each sample and was deleted. A minimum of 200 pictures was analyzed for each slide, but typically around 500 photographs per slide were analyzed.

After automatic photograph capture, counting was performed using SYRACO, an automatic coccolith recognition system (Beaufort and Dollfus, 2004). SYRACO relies on a database of photographs consisting of objects that can be commonly found in the studied slides. Within a slide, three types of objects are recorded. The first and, often, the most abundant type of object consists of unidentified calcite fragments called "invaders", which are not produced by calcareous nannofossils. The second type of object consists of calcareous nannofossils other than coccoliths, and coccoliths are the third type of object.

Our SYRACO database framework was composed of: 1) a set of 2500 photographs of calcite debris, or "invaders", which SYRACO must avoid counting; 2) different classes of objects that SYRACO must recognize (i.e., coccoliths and other calcareous nannofossils) with 150 photographs of each class. Since the SYRACO recognition system is mainly based on size, 
shape and birefringence of each object, each class groups objects strictly based on these criteria.

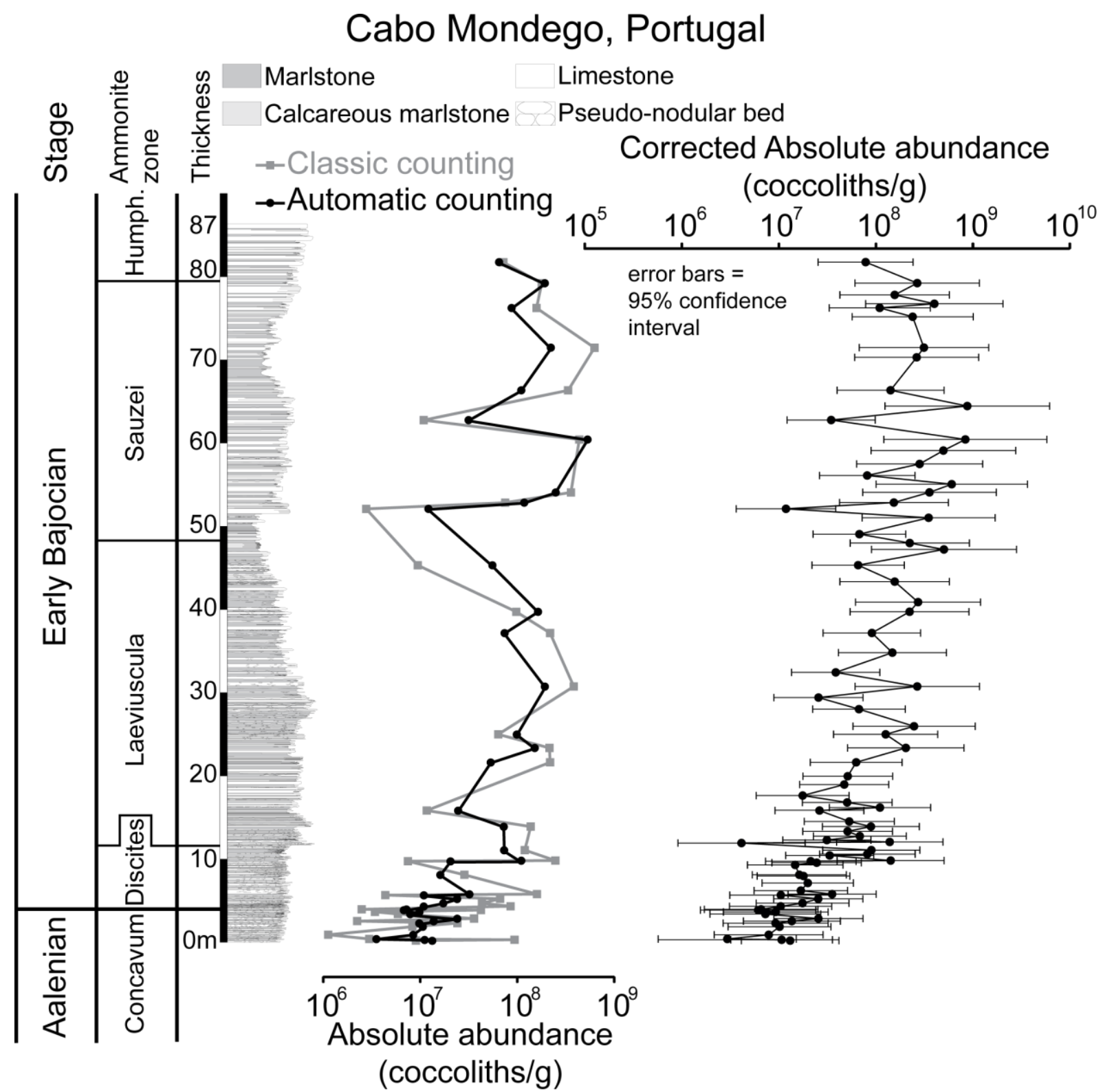

Figure 2: Stratigraphic variations of absolute abundance calculated based on automatic counting (black circles) and classic counting (gray squares) at Cabo Mondego. The corrected absolute abundance for all automatic counting samples is based on correlation regression. Error bars have been calculated based on the $95 \%$ confident band for the fitted correlation regression (see also Fig. 4).

In the Aalenian-Bajocian sediments, Schizosphaerella spp. were the only calcareous nannofossil incertae sedis found other than coccoliths. Unfortunately, the SYRACO system is not able to recognize Schizosphaerella spp., because these nannofossils consists of two thick hemispheres, often separated and only observable when focusing. Due to the SYRACO recognition process, the Aalenian-Bajocian coccoliths were previously split into classes containing several species. SYRACO cannot identify coccoliths at the species level, because many different species have similar shapes and sizes, and the taxonomic criteria defined by researchers for species identification are too subtle to be integrated into SYRACO. Therefore, each class is composed of species belonging to one or two genera. The species belonging to 
each class and the different criteria used for attributing a species to a given class are reported in Table 1. We have created two databases from Cabo Mondego coccoliths, the first of which contains only one coccolith class, namely Carinolithus spp., and the second of which contains six coccolith classes (Table 1). Carinolithus spp. in lateral view have been classified separately because their shape is very different from other coccoliths, mostly observed in proximal or distal view. The Cabo Mondego database was also used for the Chaudon-Norante samples because a preliminary control of the slides has revealed that the two sections are characterized by the same coccolith species and exhibit the same type of preservation. In order to control SYRACO counting, every result obtained automatically was also checked manually.

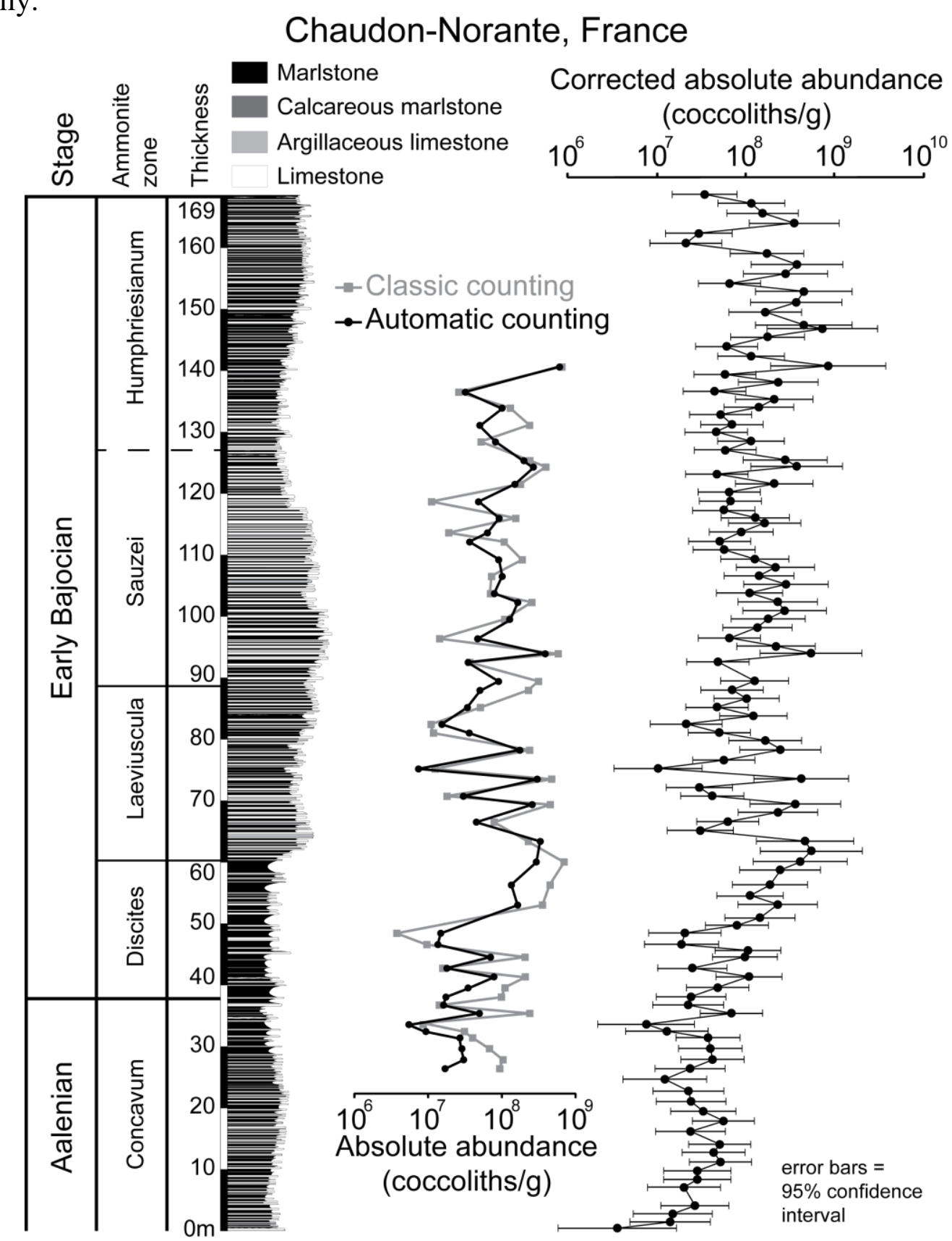

Figure 3: Stratigraphic variations of absolute abundance calculated based on automatic counting (black circles) and classic counting (gray squares) at Chaudon-Norante. The corrected absolute abundance for all automatic counting samples is based on correlation regression. Error bars have been calculated based on the $95 \%$ confident band for the fitted correlation regression (see also Fig. 4). 


\subsection{Coccolith flux calculation}

Coccolith flux was calculated using:

Flux $\left(\right.$ coccolith $\left./ \mathrm{m}^{2} / \mathrm{yr}\right)=$ Absolute abundance $($ coccolith $/ \mathrm{g}) \mathrm{x}$ sedimentation rate $(\mathrm{m} / \mathrm{Myr}) \mathrm{x}$ sediment density $\left(\mathrm{g} / \mathrm{cm}^{3}\right)$

The sedimentation rate was calculated for Chaudon-Norante based on cyclostratigraphy (Suchéras-Marx et al., 2013). Ammonite zones were defined based on the same fossil markers both in Chaudon-Norante and Cabo Mondego, and thus the two sections can be precisely correlated (Henriques et al., 1994; Pavia, 1983). Hence, sedimentation rates were calculated for each ammonite zone in both sections based on Suchéras-Marx et al. (2013) and on Gradstein et al. (2012) for the Concavum Zone at Cabo Mondego. We used the ammonite zone scale in order to provide the same precision for sedimentation rate in both sections. In each ammonite zone, the sedimentation rate was considered as constant because no hiatus or condensation levels were observed in the field.

Sediment density is dependent on the composition and porosity of the rock. 40 samples with various calcium carbonate contents were measured for density (20 from Cabo Mondego and 20 from Chaudon-Norante; see Supplementary figure 1). Densities ranged from 2.28 to 2.69 with a mean value of $2.55 \mathrm{~g} / \mathrm{cm}^{3}$. Supplementary Figure 2 shows the fluxes calculated with $95 \%$ confidence interval $(2 \sigma)$ which is presented in gray. The density range around the mean suggests a very low impact of density on the flux calculation, allowing the use of a mean value for all samples.

\begin{tabular}{|c|c|c|c|c|c|}
\hline Neural network 1 & & & & & \\
\hline Class number & 1 & & & & \\
\hline Class 1 & Carinolithus spp. side view & & & & \\
\hline Invaders & & & & & \\
\hline Neural network 2 & & & & & \\
\hline Class number & 6 & & & & \\
\hline Class 1 & Large placolith & Sub-circular to elliptical & High birefringence & & \\
\hline species example & Watznaueria contracta & W. colacicchii & W. britannica B-C-D-E-F & W. aff. manivitiae & Lotharingius velatus \\
\hline Class 2 & Small placolith & Sub-circular to elliptical & Intermediate to high birefring & ence & \\
\hline species example & W. britannica $\mathrm{A}-\mathrm{F}$ & L. hauffi & L. umbriensis & & \\
\hline Class 3 & Small to medium-size placolith & Circular to sub-circular & Intermediate birefringence & & \\
\hline species example & Discorhabdus ignotus & D. striatus & D. criotus & Similiscutum cruciulus & \\
\hline Class 4 & Small placolith & Circular to elliptical & Very low birefringence & & \\
\hline species example & Biscutum dubium & Biscutum dorsetensis & & & \\
\hline Class 5 & Large murolith & Elliptical & Very high birefringeance & & \\
\hline species example & Crepidolithus crassus & & & & \\
\hline Class 6 & Small to medium-size placolith & Elliptical & Intermediate to low birefring & ence & \\
\hline species example & B. depravatum & B. finchii & S. avitum & B. novum & \\
\hline Invaders & & & & & \\
\hline
\end{tabular}

Table 1: Description of the neural networks and associated classes. Each class has been selected based on size, shape and birefringence of coccoliths. For each class, some selected species are presented as examples.

\section{Results}

\subsection{Comparison between classic and automatic counting}

Although we successfully applied the automated system to Mesozoic nannofossils, a part of the photographs collected automatically was not of sufficient quality to support effective species recognition. Nevertheless, the photographs were good enough to distinguish coccoliths from "invaders". The results presented here were obtained after a visual checking of SYRACO results in order to avoid possible misinterpretation induced by SYRACO and eliminate the effects of residual "invaders". The absolute abundance log-log plots of classic counting versus automatic counting are presented in Figure 4 for Cabo Mondego and Chaudon-Norante. Regression correlations have been calculated for both sites with a $95 \%$ confidence interval using Past software (Hammer et al., 2001). Very good correlations were 
determined for Cabo Mondego, with $r=0.8009(\mathrm{p}<0.001)$ and Chaudon-Norante with $\mathrm{r}=$ $0.8051(\mathrm{p}<0.001)$.

Absolute abundance estimations obtained using both methods are plotted stratigraphically in Figures 2 and 3. Although an offset was observed between the values obtained with each method $(52.5 \%$ of the values obtained by automatic counting for Cabo Mondego and $64 \%$ for Chaudon-Norante were underestimated when compared to classic counting), short-time variations (from marlstone to limestone) in absolute abundance as well as long-term trends were essentially the same using both methods.

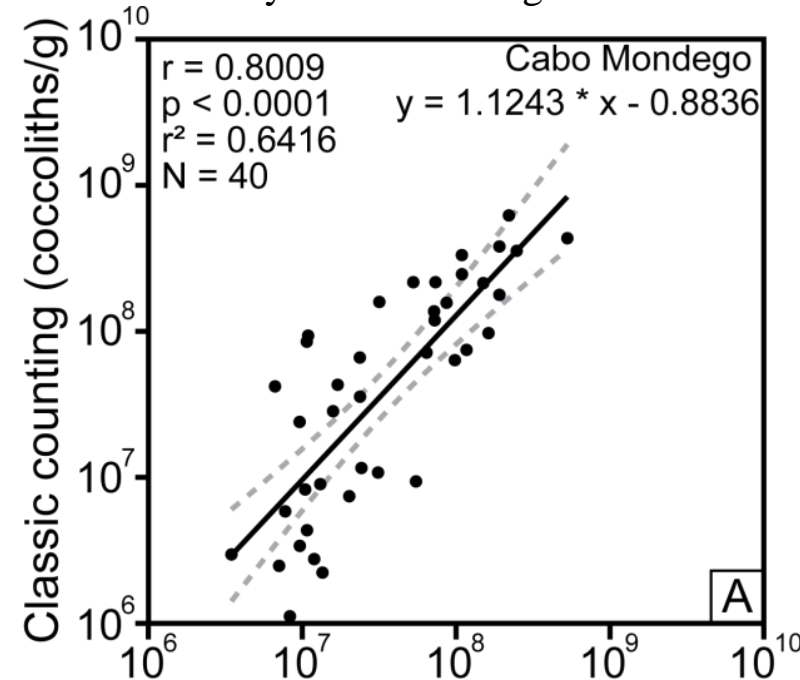

Automatic counting (coccoliths/g)

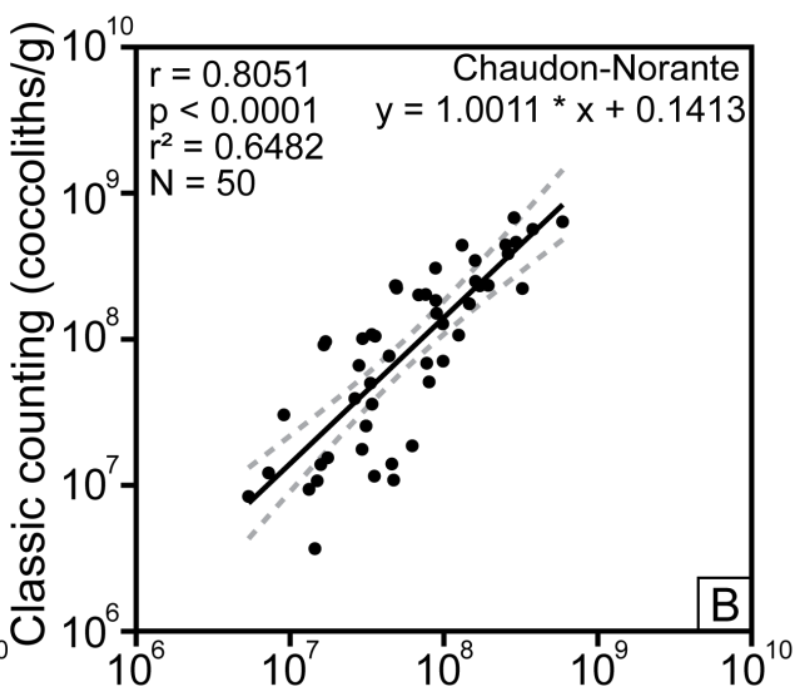

Automatic counting (coccoliths/g)

Figure 4: Regression correlation between absolute abundances (coccoliths/g) calculated based on automatic counting and classic counting for Cabo Mondego (A) and Chaudon-Norante (B). For Cabo Mondego, $r=0.8099$ and for Chaudon-Norante, $r=0.8051$. Dashed lines represent the $95 \%$ confident interval around the fitted line.

\subsection{Correction of absolute abundances based on classic counting}

About one half of the samples in each section were counted using classic counting. In order to correct the automated counting of SYRACO, a linear correlation equation between classic counting and automatic counting of absolute abundances was performed (Fig. 4). The results of automatic counting have been thus re-calculated based on the linear correlation equation for all the samples and plotted for both sections (corrected absolute abundance in Figs 2 and 3 ) with an associated error corresponding to the $95 \%$ confidence interval around the regression correlation. At Cabo Mondego (Fig. 2), the absolute abundance increased from $0.01 \times 10^{9}$ coccoliths/g at the end of the Aalenian to $0.3 \times 10^{9}$ coccoliths/g at the beginning of the Laeviuscula Zone (Early Bajocian). From then, until the top of the section, the absolute abundance varied mostly between $0.1 \times 10^{9}$ and $10^{9}$ coccoliths/g. A similar increase was observed at Chaudon-Norante from $0.01 \times 10^{9}$ to $0.1 \times 10^{9}$ coccoliths/g at the end of the Aalenian to $0.1 \times 10^{9}$ to $10^{9}$ coccoliths/g in the Early Bajocian, with the highest values recorded in the middle of the Humphriesianum Zone. A major increase in absolute abundance occurred during the Discites Zone, followed by a slight decrease in the Laeviuscula Zone. Then, after a small increase at the beginning of the Sauzei Zone, there was little variation except for short-term fluctuations related to marlstone-limestone alternation.

Figure 5: Correlation between Cabo Mondego and Chaudon-Norante with corrected absolute abundances from automatic counting, estimated fluxes based on corrected absolute abundance and $\delta^{13} C_{\text {Bulk carbonate }}(\% ;$ VPDB). Correlations are based on ammonite biostratigraphy (Pavia, 1983; Fernandez-Lopez et al., 1988). 


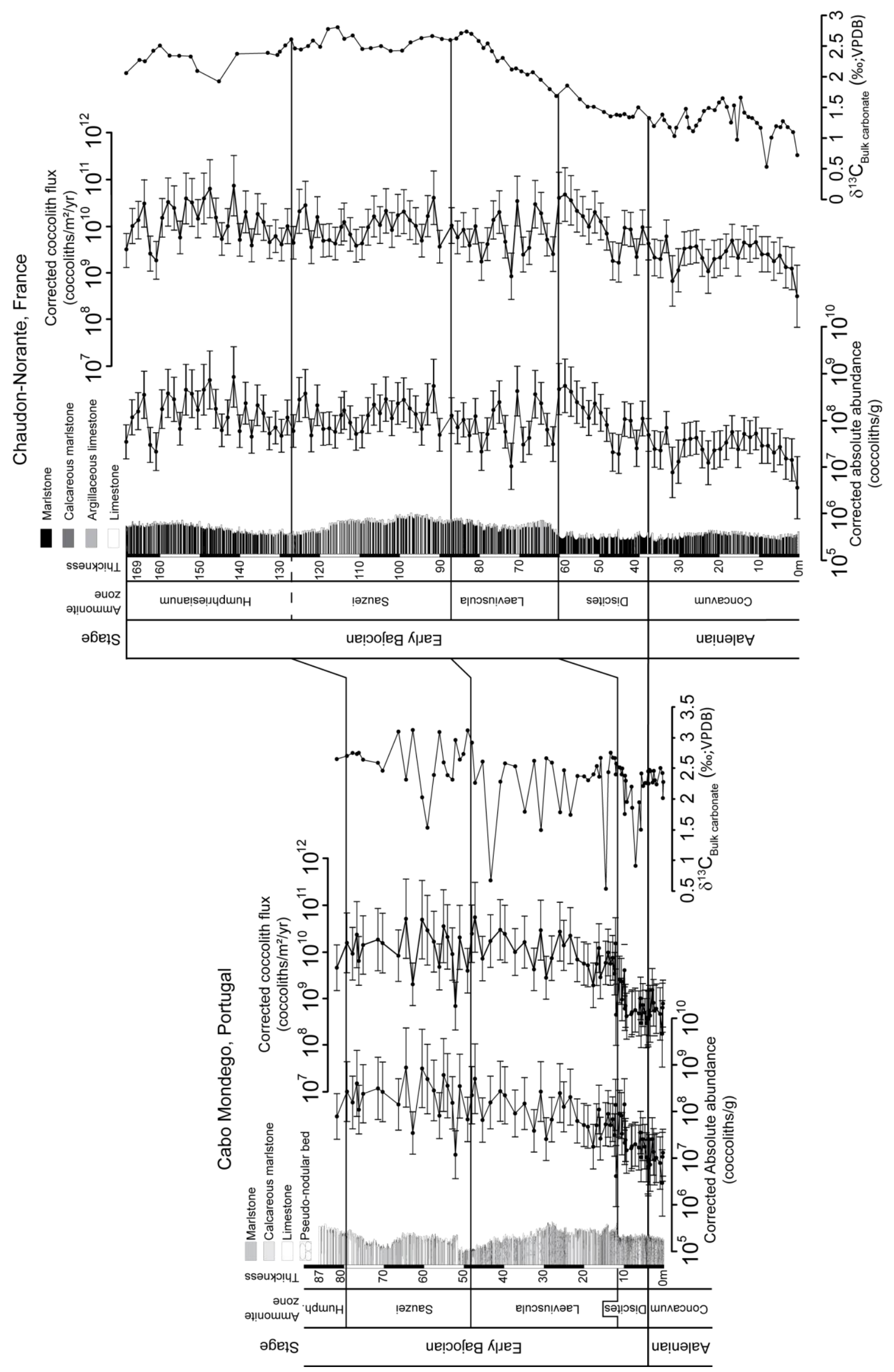




\subsection{Automatic counting and coccolith fluxes}

The sedimentation rates are lower at Cabo Mondego than at Chaudon-Norante, especially in the Aalenian and Discites Zone, where rates are three times lower in the Portuguese section than in the similar interval from the French section. Coccolith fluxes exhibit exactly the same trends as absolute abundances (Fig. 5).

Afterwards, values remained relatively high with variations between $10 \times 10^{9}$ and $50 \times 10^{9}$ coccoliths $/ \mathrm{m}^{2} / \mathrm{yr}$ related to marlstone-limestone alternations. A similar increase is observed at Chaudon-Norante, but only until the end of the Discites Zone.

The comparison between flux estimations and wt $\% \mathrm{CaCO}_{3}$ content (from Suchéras-Marx et al., 2012; Suchéras-Marx et al., 2013) reveals a decrease in coccolith fluxes while $\mathrm{CaCO}_{3}$ content increases at Cabo Mondego (Fig. 6). The maximal fluxes were found for wt $\% \mathrm{CaCO}_{3}$ values between $55 \%$ and $65 \%$. At Chaudon-Norante, there is a positive relation between nannofossil fluxes and carbonate content for wt $\% \mathrm{CaCO}_{3}$ between $20 \%$ and $35 \%$, and a negative relation for $\mathrm{wt}^{2} \mathrm{CaCO}_{3}$ between $48 \%$ and $88 \%$. The maximal fluxes were observed for calcium carbonate contents between $35 \%$ and $50 \%$ (Fig. 6).

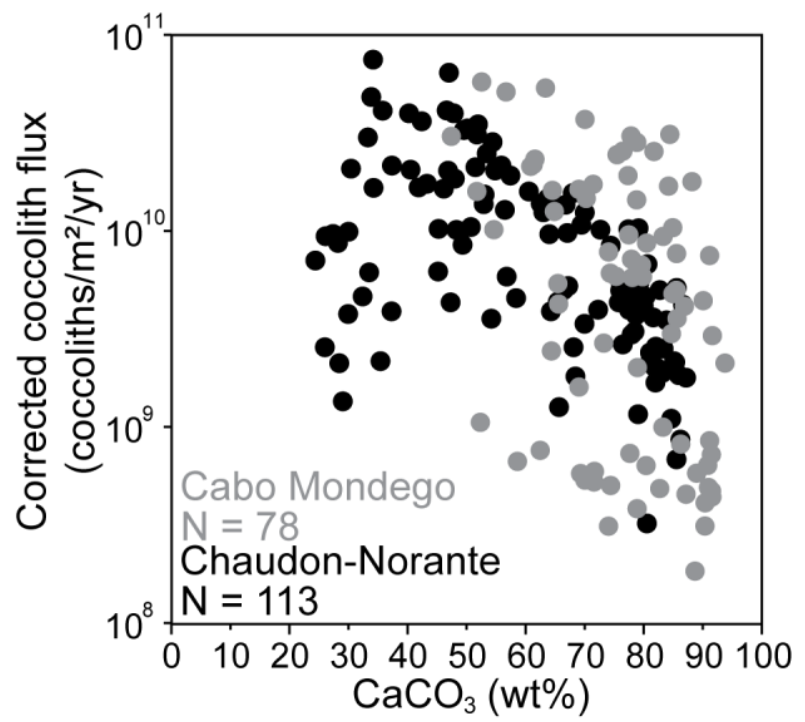

Figure 6: Plot of wt $\% \mathrm{CaCO}_{3}$ versus corrected coccolith flux (coccoliths $/ \mathrm{m}^{2} /$ year). Samples from Cabo Mondego are represented in gray and those from Chaudon-Norante in black.

\section{Discussion}

5.1. Impact of preservation on absolute abundance

The correlation of absolute abundances calculated using classic and automatic counting might be dependent on coccolith preservation, which can render identification by SYRACO difficult. We tested the impact of preservation state on absolute abundance using the Bonferroni/Dunn test with 95\% confidence interval (Fig.7). This test was performed on both classic counting of absolute abundances (Fig. 7A and 7B) and automatic counting of absolute abundances (Fig. 7C and 7D). Classic counting of absolute abundances at Cabo Mondego were likely not related to preservation (Fig. 7A) whereas at Chaudon-Norante "Poor" preservation influenced coccolith absolute abundances. These results are confidently different in "Moderate" and "Good" preservation samples (Fig. 7B). For automatic counting of absolute abundances at Cabo Mondego, "Poor" preservation was only confidently different from "Good" preservation (Fig. 7C). The same result was obtained for SYRACO absolute abundances at Chaudon-Norante (Fig. 7D). Thus, we infer that "Poor" preservation states influence absolute abundance estimations and especially for automatic counting made by SYRACO, by complicating the potential identification of coccoliths. 
Cabo Mondego
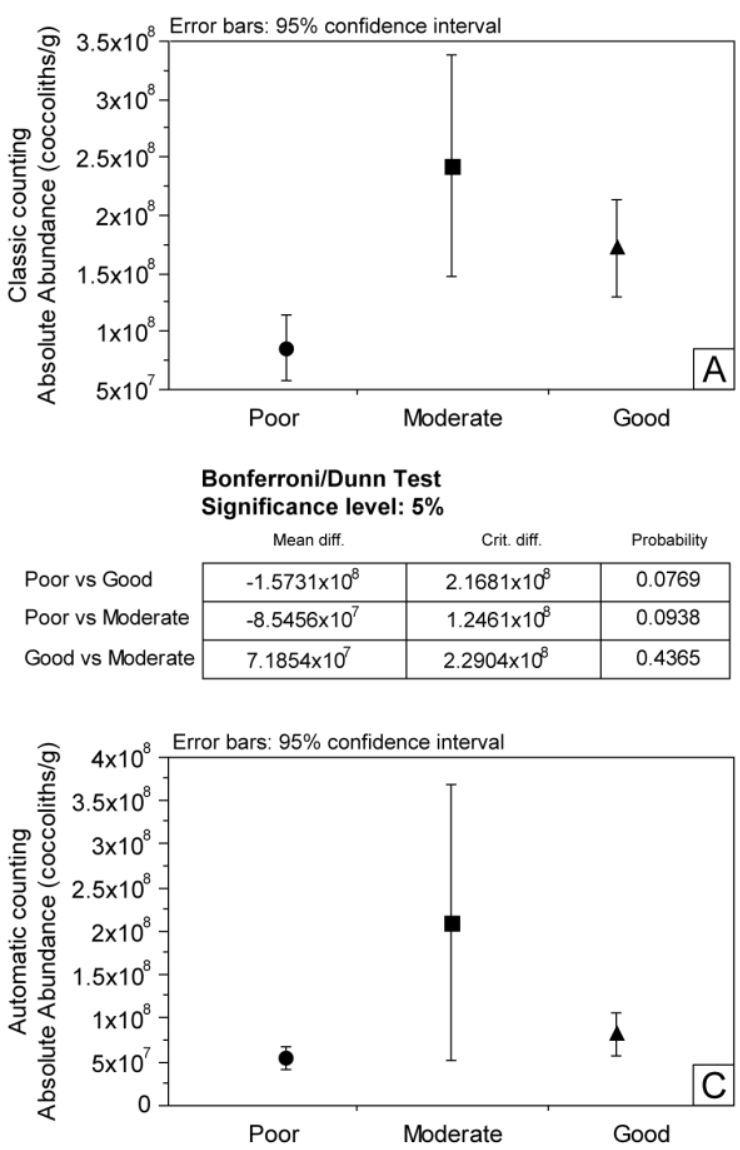

Bonferroni/Dunn Test

Significance level: $\mathbf{5} \%$

\begin{tabular}{|c|c|c|c|}
\hline & Mean diff. & Crit. diff. & Probability \\
\hline Poor vs Good & $-1.5456 \times 10^{8}$ & $1.4284 \times 10^{8}$ & 0.0101 \\
\hline Poor vs Moderate & $-2.5758 \times 10^{7}$ & $8.4583 \times 10^{7}$ & 0.4494 \\
\hline Good vs Moderate & $1.2882 \times 10^{8}$ & $1.5227 \times 10^{8}$ & 0.0406 \\
\hline
\end{tabular}

\section{Chaudon-Norante}
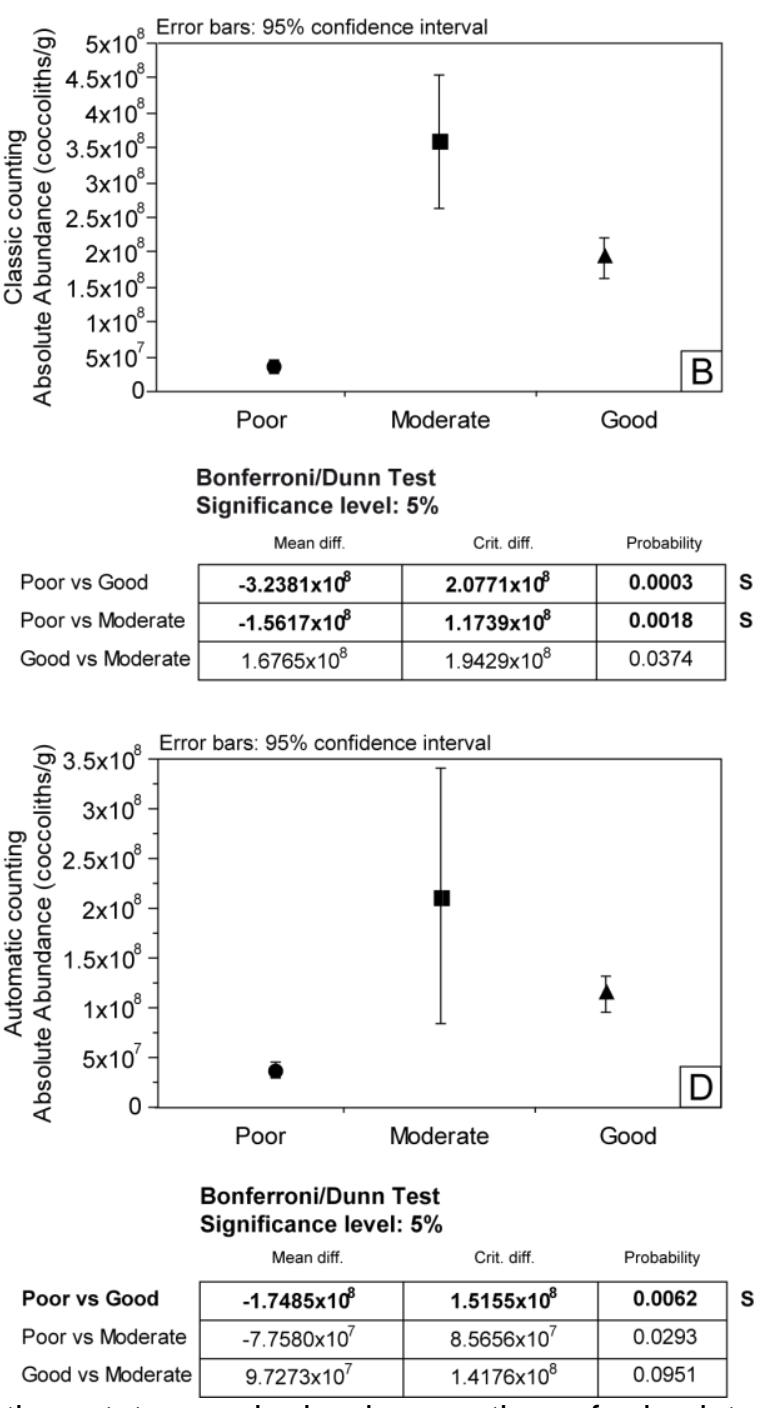

Figure 7: Bonferroni/Dunn test between preservation states and classic counting of absolute abundances at Cabo Mondego (A) and Chaudon-Norante (B), and between preservation states and automatic counting of absolute abundances at Cabo Mondego (C) and Chaudon-Norante (D).

\subsection{Absolute abundance estimation}

SYRACO databases and neural networks were generated using coccoliths from Cabo Mondego, but they are applicable to Chaudon-Norante because both sections have the same species composition and coccolith preservation level. SYRACO absolute abundance estimation is a reliable method based on the strong linear correlation between classic and automatic counting. Nevertheless, automatic counting tends to underestimate the absolute abundance calculated by classic counting in 52.5\% samples for Cabo Mondego and 64\% samples for Chaudon-Norante (Fig. 8). It should be stated that all other samples are overestimated, it is almost impossible to obtain exactly the same values, absolute abundance range being naturally too high. The tendency of automatic counting to underestimate absolute abundance could be due to the influence of poor preservation encountered in certain samples, and also the difficulty in SYRACO coccolith recognition for blurry photographs. Even if each picture was carefully checked for its focus before SYRACO counting, photographs with a slightly incorrect focus can be relatively common. This technical limit may induce reduced coccolith recognition in automatic counting. This problem may also be related to the abundance of objects recognized by SYRACO as "invaders", as they are dominant 
components in most of the slides studied, and especially in limestones (Fig. 6). The correlation plot between $\mathrm{wt} \% \mathrm{CaCO}_{3}$ content and the ratio between classic and automatic counting of absolute abundances (Fig. 8) suggests that, in general, SYRACO overestimates coccolith absolute abundance in carbonate-rich samples and underestimates coccolith absolute abundance in clay-rich samples. This observation suggests that SYRACO possibly attributes some "invaders" to the coccolith class, especially in carbonate-rich samples in which there is an excess of "invaders". We thus infer that the presence of "invaders" is not responsible for coccolith loss in carbonate-poor samples, which seems to be a different problem affecting the SYRACO counting.

Despite these problems, short-term trends, such as higher coccolith absolute abundance in marlstones than in limestones, as well as long-term trends, such as the abundance increase from Aalenian to Bajocian, were observed in the automatic counting results. Despite the fact that automatic counting introduces underestimation of coccolith absolute abundance, the same variations of absolute abundances are observed when automatic and classic counting are compared. This underestimation related to the automatic counting can be corrected using a linear correlation equation, calculated by comparing the results obtained with the two methods of counting on few samples. Thus, the automatic counting can be considered a reliable method for absolute abundance quantification as well as for coccolith flux determination in Mesozoic deposits.

\subsection{Technical issues}

The automatic counting method has provided reliable results, however there are still some technical issues that need to be improved in the future. The main problem involves the automatic capture system. Some pictures are blurry and it is time-consuming to check them all in order to verify that coccolith identification is still possible using SYRACO. These difficulties in coccolith identification may somehow lower the quality of the dataset obtained, without reducing the time spent to produce data. The blurry pictures generated by the predictive focus can be related to 1) the presence of large particles in the rock powder that may produce an irregular surface of the covering slide, or 2) the instability of our mechanical device, which can produce a slight tilt of the slide while it is moved laterally. These two problems are difficult to solve, unless an autofocus is added to the system. This solution is attractive but the autofocus is dependent on the size of the object ("invaders" and coccoliths) in the field of view, which can only be controlled if samples are sieved before preparation. Sieving can, however, add a further possible coccolith or nannolith loss. So far no autofocus solution for SYRACO has produced better focus than predictive focus.

\subsection{Influence of paleoclimate and paleoenvironmental conditions on coccolith fluxes}

Coccolith fluxes from the end of the Aalenian to the Early Bajocian increased 10 to 100 times in the two studied sections (based on classic or automatic counting). This major increase is related to the increase in Watznaueria absolute abundance and flux (quantified at Cabo Mondego by Suchéras-Marx et al., 2012). This flux increase is synchronous between Cabo Mondego and Chaudon-Norante, but at Cabo Mondego, the main phase of the increase ends in the Laeviuscula Zone while at Chaudon-Norante it ends earlier, at the end of the Discites Zone. Conversely, the slight flux decrease observed at Chaudon-Norante during the Laeviuscula Zone was not observed at Cabo Mondego.

The Cabo Mondego and Chaudon-Norante sections are located in different basins that were not directly connected to each other. Cabo Mondego was located in the Lusitanian Basin, which was open westward to the Proto-Atlantic Ocean, while Chaudon-Norante is in the French Subalpine Basin, open eastwards towards the Tethys Ocean. These different paleogeographic contexts may explain the slight difference in the coccolith increase pattern 
related to local influences. Nevertheless, the coccolith flux increase is synchronous between the two sections, and thus can be considered as a supra-regional event.

The Early Bajocian has been described as an interval showing an increase in the oceanic fertility mostly based on i) a change in radiolarian assemblages and increase in radiolarian sedimentation (Bartolini et al., 1999; Bartolini and Cecca, 1999) and ii) a $\delta^{13} C_{\text {Bulk carbonate }}$ positive excursion recorded in many European sections (Corbin, 1994; Bartolini et al., 1996; Jenkyns et al., 2002; O’Dogherty et al., 2006; Brigaud et al., 2009; Suchéras-Marx et al., 2012 ; 2013) resulting from a change in carbon reservoir composition. Coincident with the positive $\delta^{13} \mathrm{C}$ excursion and the diversification of radiolarians, coccolith absolute abundances and fluxes increase both in Lusitanian and Vocontian basins. It is intriguing that the Early Bajocian situation for positive $\delta^{13} \mathrm{C}$ excursion , radiolarians and coccoliths can be compared with that of the Valanginian Weissert Event. The Early Bajocian and Valanginian positive carbon excursions are of moderate amplitude lower than $2 \%$ with maximum values of $\delta^{13} C_{\text {Bulk carbonate }}$ around 3\%o (Corbin, 1994; Bartolini et al., 1996; O'Dogherty et al., 2006; Sprovieri et al., 2006; Duchamp-Alphonse et al., 2007; Bornemann and Mutterlose, 2008; Gréselle et al., 2011; Charbonnier et al., 2013; Suchéras-Marx et al., 2013). Moreover, during the Weissert Event, the radiolarian trend is towards the diversification (Jud, 1994) and the nannofossil or coccolith absolute abundances or fluxes increase (Bornemann and Mutterlose, 2008; Gréselle et al., 2011), the absolute abundance of the meso-eutrophic D. lehmanii species and W. barnesiae increase (Erba and Tremolada, 2004). But there is a decrease in absolute abundance of narrow-canal nannoconids resulting in a decrease in nannofossil carbonate fluxes (Erba and Tremolada, 2004). However during this event there no consensus concerning the nannofossil carbonate paleofluxes since Erba and Tremolada (2004) show a decrease whereas Gréselle et al. (2011) show an increase. Nevertheless, it should be stated that nannofossil carbonate paleofluxes is no equivalent to nannofossil fluxes.

Increase in nannofossil absolute abundances and/or fluxes are not always associated with

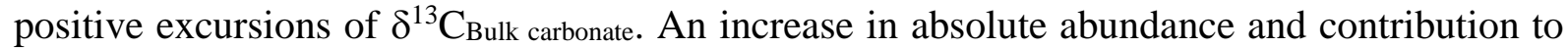
pelagic sedimentation occurred in the Tithonian-Berriasian interval (7 Ma; Gradstein et al., 2012) characterized by a long lasting steady $C$ isotopic values (Bornemann et al., 2003; Casellato, 2009). However, positive excursions of $\delta^{13} C_{\text {Bulk carbonate }}$ could be associated with decrease in nannofossil absolute abundances and/or fluxes. During the Mid-Cenomanian Event I characterized by two positive peaks (MCE Ia and b) with maximum carbon isotope values around 3\%o and amplitude of the shifts below 2\%o, a decrease both in nannofossil absolute abundances and fluxes is recorded (Hardas et al., 2012; Giraud et al., 2013). The

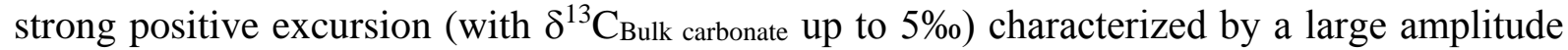
(higher than 2\%o) recorded during the Cenomanian/Turonian Boundary or OAE (Oceanic Anoxic Event2), is associated with extinction within the radiolarian assemblages (O’Dogherty, 1994) and a decrease in nannofossil abundances (Linnert et al., 2011 and references herein). The duration of the excursions is conversely different between the Early Bajocian and the Valanginian positive shifts and that of the Cenomanian. The duration of the $\delta^{13} \mathrm{C}$ positive excursions of both the Early Bajocian and the Valanginian is estimated to be around 4 Myr for the first one (Suchéras-Marx et al., 2013) and between 1.5 and 2.3 Myr for the second one (Sprovieri et al., 2006; Gréselle et al., 2011; Charbonnier et al., 2013; Martinez et al., 2013), whereas the positive excursions of the Cenomanian are largely shorter (less than $400 \mathrm{kyr}$ for the MCE I; Reboulet et al., 2013, and between 197 and $601 \mathrm{ka}$ according to different authors for the OAE2; Kuhnt et al., 2005; Voigt et al., 2008; Sageman et al., 2006). The differences in the duration of the excursions can be explained by variations in the timing of the marine fertility rise. For Bartolini et al. (1999), the trend towards diversification within the radiolarians recorded both during the Early Bajocian and the Valanginian could be linked to a gradual increase in marine trophic ressources, whereas 
during other intervals such as the Cenomanian/Turonian Boundary, a sudden and rapid increase of nutrients within the ocean realm could be involved. It seems that a gradual oceanic fertilization, but not a true eutrophication event, could be favorable to the increase in calcareous nannofossil fluxes.

The oceanic fertilization during the Early Bajocian has been linked to a climatic change. A warming in the Tethys Ocean has been suggested for the end of the Early Bajocian based on $\delta^{18} \mathrm{O}$ of biogenic calcite (see compilation in Dera et al., 2011). The Early Bajocian has been identified as a humid period based on coal/charcoal deposits in England (Hesselbo et al., 2003), and also as warm and humid period based on clay mineralogy in France and Hungary (Raucsik et al., 2001; Raucsik and Varga, 2008; Brigaud et al., 2009). This increase in temperature might have been triggered by an increase of $p \mathrm{CO}_{2}$ due to increased volcanic activity related to Pacific plate formation (Bartolini and Larson, 2001), as deduced from the stomatal densities of leaf cuticles from the Aalenian/Bajocian Boundary of England (Hesselbo et al., 2003). Oceanic fertilization was likely induced by enhanced weathering due to the warming and humid climatic conditions.

We suggest that the increase in coccolith fluxes in both France and Portugal occurring during the same time interval as the increase in radiolarian sedimentation observed in some basins, and the $\delta^{13} \mathrm{C}$ positive excursion resulted from a gradual increase in fertility of the oceans due to enhanced continental weathering and nutrient delivery to surface oceans.

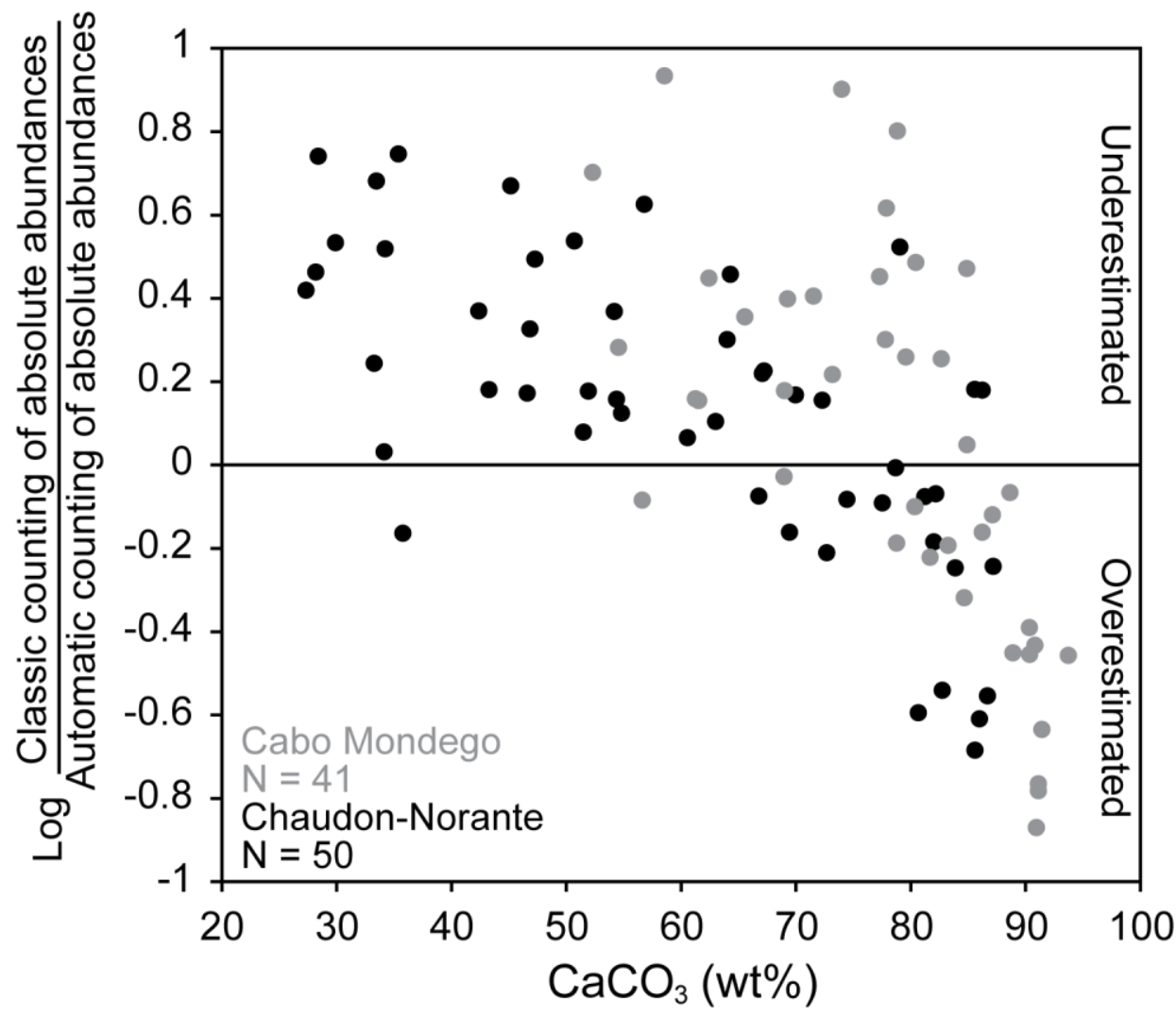

Figure 8: Plot of wt\% $\mathrm{CaCO}_{3}$ versus the log ratio of classic counting/automatic counting of absolute abundances. Samples from Cabo Mondego are represented in gray and those from Chaudon-Norante in black. The log of the ratio was taken in order to center the data around 0 , where 0 represents no difference between classic and automatic counting methods. SYRACO underestimated samples are found between 0 and 1 , whereas overestimated samples are found between -1 and 0 . 


\section{Conclusions}

In this study, we quantified coccolith fluxes during the latest Aalenian-Early Bajocian at Cabo Mondego, Portugal and Chaudon-Norante, France by applying for the first time an automatic counting methodology to Mesozoic samples. The main outputs of this study are the following.

- Automatic counting using SYRACO (Beaufort and Dollfus, 2004) is a reliable method for absolute abundance and coccolith flux quantification for Mesozoic deposits with strong linear correlations $(r>0.8)$ between classic and automatic counting.

- Further technical improvements are needed for a fully automatic recognition system such as implementation of an automatic focus.

- The onset of the increase in coccolith absolute abundances and fluxes in the latest Aalenian-Early Bajocian is synchronous between the Lusitanian Basin and the French Subalpine Basin and can be viewed as a supra-regional event.

- The Early Bajocian time interval is similar to the Valanginian Weissert Event in terms of duration and amplitude of the positive $\delta^{13} \mathrm{C}_{\text {Bulk carbonate }}$ excursion, the radiolarian diversification and the coccolith absolute abundance increase.

- The increase in the calculated coccolith flux was a consequence of a gradual fertilization of the oceans due to enhanced continental weathering and nutrient delivery.

The coccolith flux increase during the Early Bajocian matches the diversification of Watznaueria (Suchéras-Marx et al., 2012). Thus, more investigations are needed to understand the impact of Watznaueria diversification on nannofossil community changes as well as the interplay of this diversification with inferred ocean fertilization.

\section{Acknowledgements}

Remarks by Jorijntje Henderiks and Paul Bown greatly improved an earlier version of the manuscript. We are also grateful to Matthew Makou for english corrections and two anonymous reviewers and Richard Jordan for comments on an earlier version of the manuscript. This paper is a part of B.S-M.'s PhD project funded by the French Ministry of Research and supported by BQR UCBL Lyon1 2006 to F.G., BQR UCBL Lyon 12010 and INSU 2011-12 Syster/Interrvie to E.M. This paper is a contribution of the team Paléoenvironnements to the UMR CNRS 5276 (UCBL) and to Uppsala University Paleobiology Programme.

\section{References}

Bartolini, A., Baumgartner, P. O., Guex, J., 1999. Middle and Late Jurassic radiolarian palaeoecology versus carbon-isotope stratigraphy. Palaeogeography, Palaeoclimatology, Palaeoecology 145, 43-60.

Bartolini, A., Baumgartner, P.O., Hunziker, J.C., 1996. Middle and Late Jurassic carbon stable-isotope stratigraphy and radiolarite sedimentation of the Umbria-Marche Basin (Central Italy). Eclogae Geologicae Helvetiae 89, 811-844.

Bartolini, A., Cecca, F., 1999. 20 My hiatus in the Jurassic of Umbria-Marche Apennines (Italy): Carbonate crisis due to eutrophication. Comptes Rendus Académies des Sciences 329, 587-595.

Bartolini, A., Larson, R.L., 2001. Pacific microplate and the Pangea supercontinent in the Early to Middle Jurassic. Geology 29, 735-738.

Beaufort, L., 1991. Adaptation of the random settling method for quantitative studies of calcareous nannofossils. Micropaleontology 37, 415-418.

Beaufort, L., Couapel, M., Buchet, N., Claustre, H., Goyet, C., 2008. Calcite production by Coccolithophores in the South East Pacific Ocean. Biogeosciences, 5: 1101-1117. 
Beaufort, L., Dollfus, D., 2004. Automatic recognition of coccoliths by dynamical neural networks. Marine Micropaleontology 51, 57-73.

Beaufort, L., Probert, I., De Garidel-Thoron, T., Bendif, E. M., Ruiz-Pino, D., Metzl, N., Goyet, C., Buchet, N., Coupel, P., Grelaud, M., Rost, B., Rickaby, R. E. M., De Vargas, C., 2011. Sensitivity of coccolithophores to carbonate chemistry and ocean acidification. Nature 476, 80-83.

Blakey, R.C. , 2008. Gondwana paleogeography from assembly to breakup-A 500 m.y. odyssey. Geological Society of America Special Papers 441, 1-28.

Bornemann, A., Aschwer, U., Mutterlose, J., 2003. The impact of calcareous nannofossils on the pelagic carbonate accumulation across the Jurassic-Cretaceous boundary. Palaeogeography, Palaeoclimatology, Palaeoecology 199,187-228.

Bornemann, A., Mutterlose, J., 2008. Calcareous nannofossil and $\delta^{13} \mathrm{C}$ records from the early Cretaceous of the western Atlantic ocean: evidence for enhanced fertilization across the Berriasian-Valanginian transition. Palaios 23, 821-832.

Bown, P.R., 2005. Calcareous nannoplankton evolution: a tale of two oceans. Micropaleontology 51 (4), 299-308.

Brigaud, B., Durlet, C., Deconinck, J.-F., Vincent, B., Pucéat, E., Thierry, J., Trouiller, A., 2009. Facies and climate/environmental changes recorded on a carbonate ramp: A sedimentological and geochemical approach on Middle Jurassic carbonates (Paris Basin, France). Sedimentary Geology 222, 181-206.

Casellato, C. E., 2009. Causes and consequences of calcareous nannoplankton evolution in the Late Jurassic: implications for biogeochronology, biocalcification and ocean chemistry. PhD Thesis, Università degli Studi di Milano, Dipartimento di Scienze della Terra, Milano, pp. 116.

Charbonnier, G., Boulila, S., Gardin, S., Duchamp-Alphonse, S., Adatte, T., Spangenberg, J.E., Föllmi, K.B., Colin, C., Galbrun, B., 2013. Astronomical calibration of the Valanginian "Weissert" episode: The Orpierre marl-limestone succession (Vocontian Basin, southeastern France). Cretaceous Research 45, 25-42.

Cobianchi, M., Erba, E., Pirini-Radrizzani, C., 1992. Evolutionary trends of calcareous nannofossil genera Lotharingius and Watznaueria during the Early and Middle Jurassic. Memorie di Scienze Geologiche, Padova 43, 19-25.

Corbin, J.C., 1994. Evolution géochimique du Jurassique du Sud-Est de la France : influence du niveau marin et de la tectonique. Unpublished PhD Thesis, Paris VI. 198 pp.

Dera, G., Brigaud, B., Monna, F., Laffont, R., Puceat, E., Deconinck, J.-F., Pellenard, P., Joachimski, M. M., Durlet, C., 2011. Climatic ups and downs in a disturbed Jurassic world. Geology 39, 215-218.

Dollfus, D., Beaufort, L., 1999. Fat neural network for recognition of position-normalised objects. Neural Networks 12, 553-560.

Duchamp-Alphonse, S., Gardin, S., Fiet, N., Bartolini, A., Blamart, D., Pagel, M., 2007. Fertilization of the northwestern Tethys (Vocontian basin, SE France) during the Valanginian carbon isotope perturbation: Evidence from calcareous nannofossils and trace element data. Palaeogeography, Palaeoclimatology, Palaeoecology 243(1-2), 132-151.

Erba, E., 1990. Calcareous nannofossil biostratigraphy of some Bajocian sections from the Digne area (SE France). Memorie Descrittive Della Carta Geologica d'Italia XL, 237-256.

Erba, E., 2006. The first 150 million years history of calcareous nannoplankton: Biospheregeosphere interactions. Palaeogeography, Palaeoclimatology, Palaeoecology 232, 237-250.

Erba, E., Pavia, G., 1990. Record of the discussion about the proposals for the Bajocian G.S.S.P. Memorie Descrittive Della Carta Geologica d'Italia XL, 63-68. 
Erba, E., Tremolada, F., 2004. Nannofossil carbonate fluxes during the Early Cretaceous: Phytoplankton response to nutrification episodes, atmospheric $\mathrm{CO}_{2}$, and anoxia. Paleoceanography 19(1), PA1008, doi:10.1029/2003PA000884.

Fernandez-Lopez, S., Henriques, M.H., Mouterde, R., Rocha, R.B., Sadki, D., 1988. Le Bajocien inférieur du Cap Mondego (Portugal) - Essai de biozonation. $2^{\text {nd }}$ International Symposium on Jurassic Stratigraphy, Lisboa, 301-313.

Fernandez-Lopez, S., Pavia, G., Erba, E., Guiomar, M., Henriques, M. H., Lanza, R., Mangold, C., Olivero, D., Tiraboschi, D., 2009. The Global Boundary Stratotype Section and Point (GSSP) for base of the Bathonian Stage (Middle Jurassic), Ravin du Bès Section, SE France. Episodes 32 (4), 222-248.

Geisen, M., Bollmann, J., Herrle, J. O., Mutterlose, J., Young, J. R., 1999. Calibration of the random settling technique for calculation of absolute abundances of calcareous nannoplankton. Micropaleontology 45 (4), 437-442.

Gidon, M., Pairis, J. L., 1992. The influence of the Digne thrust emplacement upon the

autochthonous structures of Bes Valley, Alpes-de-Haute-Provence, France. Eclogae Geologicae Helvetica 85, 327-359.

Giraud, F., Reboulet, S., Deconinck, J.-F., Martinez, M., Carpentier, A., Bréziat, C., 2013. The Mid-Cenomanian Event in southeastern France: Evidence from palaeontological and clay mineralogical data. Cretaceous Research 46, 43-58.

Gradstein, F. M., Ogg, J. G., Schmitz, M. D., Ogg, G. M., 2012. The geologic Time scale 2012 volume 2. Elsevier, Amsterdam.

Gréselle, B., Pittet, B., Mattioli, E., Joachimski, M., Barbarin, N., Riquier, L., Reboulet, S., Pucéat, E., 2011. The Valanginian isotope event: A complex suite of palaeoenvironmental perturbations. Palaeogeography, Palaeoclimatology, Palaeoecology 306, 41-57.

Hammer, Ø., Harper, D. A.T., Ryan, P. D., 2001. PAST: paleontological statistics software package for education and data analysis. Palaeontologia Electronica 4, 1-9.

Hardas, P., Mutterlose, J., Friedrich, O., Erbacher, J., 2012. The Middle Cenomanian Event in the equatorial Atlantic: The calcareous nannofossil and benthic foraminiferal response. Marine Micropaleontology 96-97, 66-74.

Hay, W. W., 2004. Carbonate fluxes and calcareous nannoplankton, In: Thierstein, H.R., Young, J.R. (Eds.), Coccolithophores : From molecular processes to global impact. Springer-Verlag, Berlin Heidelberg, 509-527.

Henriques, M. H., Gardin, S., Gomes, C. R., Soares, A. F., Rocha, R. B., Marques, J.F., Lapa, M. R., Montenegro, J. D., 1994. The Aalenian-Bajocian boundary at Cabo Mondego (Portugal). In: Cresta, S., Pavia, G. (Eds.), 3rd International Meeting on Aalenian and Bajocian Stratigraphy. Miscellanea Servizio Geologico Nazionale, Marrakesh, 63-77.

Hesselbo, S.P., Morgans-Bell, H.S., McElwain, J.C., Rees, P.M., Robinson, S.A., Ross, C.E., 2003. Carbon-cycle perturbation in the middle Jurassic and accompanying changes in the terrestrial paleoenvironment. The Journal of Geology 111, 259-276.

Jenkyns, H. C., Jones, C. E., Gröcke, D. R., Hesselbo, S. P., Parkinson, P. N., 2002. Chemostratigraphy of the Jurassic System: applications, limitations and implications for palaeoceanography. Journal of the Geological Society, London 159, 351-378.

Jud, R., 1994. Biochronology and systematics of Early Cretaceous Radiolaria of the Western Tethys. Mémoires de Géologie de Lausanne 19, 147 pp.

Kuhnt, W., Luderer, F., Nederbragt, S., Thurow, J., Wagner, T., 2005. Orbital-scale record of the late Cenomanian-Turonian oceanic anoxic event (OAE-2) in the Tarfaya Basin (Morocco). International Journal of Earth Sciences 94(1), 147-159.

Lees, J. A., Bown, P. R., Mattioli, E., 2005. Problems with proxies? Cautionary tales of calcareous nannofossil paleoenvironmental indicators. Micropaleontology 51(4), 333-343. 
Lemoine, M., 1973. About gravity gliding tectonics in the western Alps, In: De Jong, K.A., Scholten, R. (Eds.), Gravity and tectonics. John Wiley \& Sons, New York, 201-216.

Linnert, C., Mutterlose, J., Mortimore, R., 2011. Calcareous nannofossils from Eastbourne (Souteastern England) and the paleoceanography of the Cenomanian-Turonian boundary interval. Palaios 26(5), 298-313.

Martinez, M., Deconinck, J.-F., Pellenard, P., Reboulet, S., Riquier, L., 2013. Astrochronology of the Valanginian Stage from reference sections (Vocontian Basin, France) and palaeoenvironmental implications for the Weissert Event. Palaeogeography, Palaeoclimatology, Palaeoecology 376, 91-102.

Mattioli, E., Erba, E., 1999. Synthesis of calcareous nannofossil events in tethyan Lower and Middle Jurassic successions. Rivista Italiana di Paleontologia e Stratigrafia 105 (3), 343376.

Mattioli, E., Pittet, B., 2002. Contribution of calcareous nannoplankton to carbonate deposition: a new approach applied to the Lower Jurassic of central Italy. Marine Micropaleontology 45, 175-190.

O’Dogherty, L., 1994. Middle Cretaceous Radiolaria Biochronology and Paleontology from Umbria Apennines (central Italy) and Betic Cordillera (Spain). Mémoires de Géologie de Lausanne 21, 351pp.

O'Dogherty, L., Sandoval, J., Bartolini, A., Bruchez, S., Bill, M., Guex, J., 2006. Carbonisotope stratigraphy and ammonite faunal turnover for the Middle Jurassic in the Southern Iberian palaeomargin. Palaeogeography, Palaeoclimatology, Palaeoecology 239, 311-333.

Pavia, G., 1973. Ammoniti del Baiociano superiore di Digne (Francia SE, Dip. Basses-Alpes). Bollettino della Societa Paleontologica Italiana 19, 75-142.

Pavia, G., 1983. Ammoniti e biostratigrafia del Baiociano inferiore di Digne (Francia SE, Dip. Alpes-Haute-Provence). Monografie Museo Regionale di Scienze Naturali (Torino), pp. 254.

Pavia, G., Enay, R., 1997. Definition of the Aalenian-Bajocian Stage boundary. Episodes 20 (1), 16-22.

Prins, B., 1967. Evolution and stratigraphy of coccolithinids from Lower and Middle Lias. In: Brönnimann, P., Renz, H. H. (Eds.), Proceedings First International Conference on Planktonic Microfossils, Geneva. E. Brill, Leiden, vol. II, 547-558.

Raucsik, B., Varga, A., 2008. Climato-environmental controls on clay mineralogy of the Hettangian-Bajocian successions of the Mecsek Mountains, Hungary: An evidence for extreme continental weathering during the early Toarcian oceanic anoxic event. Palaeogeography, Palaeoclimatology, Palaeoecology 265(1-2), 1-13.

Raucsik, B., Demény, A., Borbély-Kiss, I., Szabó, G., 2001. Monsoon-like climate during the Bajocian. Clay mineralogical and geochemical study on a limestone/marl alternation (Komló Calcareous Marl Formation, Mecsek Mountains, Southern Hungary). Hantkeniana 3, 149-176.

Reboulet, S., Giraud, F., Colombié, C., Carpentier, A., 2013. Integrated stratigraphy

of the Lower and Middle Cenomanian in a Tethyan section (Blieux, southeast

France) and correlations with Boreal basins. Cretaceous Research 40, 170-189.

Roth, P. H., 1983. Calcareous nannofossils in mid-Cretaceous black shale cycles from the Atlantic and Pacific: Effects of diagenesis. EOS 64, 733-734.

Roth, P .H., 1989. Ocean circulation and calcareous nannoplankton evolution during the Jurassic and Cretaceous. Palaeogeography, Palaeoclimatology, Palaeoecology 74, 111-126.

Ruget-Perrot, C., 1961. Etudes stratigraphiques sur le Dogger et le Malm inférieur du Portugal au Nord du Tage. Memoria Serviços Geologicos de Portugal 7, 1-197.

Sageman, B.B., Meyers, S.R., Arthur, M.A., 2006. Orbital time scale and new C-isotope record for Cenomanian-Turonian boundary stratotype. Geology 34(2), 125-128. 
Sprovieri, M., Coccioni, R., Lirer, F., Pelosi, N., Lozar, F., 2006. Orbital tuning of a lower Cretaceous composite record (Maiolica Formation, central Italy). Paleoceanography 21, PA4212, doi:10.1029/2005PA001224.

Suan, G., Mattioli, E., Pittet, B., Mailliot, S., Lécuyer. C., 2008. Evidence for major environmental perturbation prior to and during the Toarcian (Early Jurassic) Oceanic Anoxic Event from the Lusitanian Basin, Portugal. Paleoceanography 23, PA1202, doi:10.1029/2007PA001459.

Suchéras-Marx, B., Guihou, A., Giraud, F., Lécuyer, C., Allemand, P., Pittet, B., Mattioli, E., 2012. Impact of the Middle Jurassic diversification of Watznaueria (coccolith-bearing algae) on the carbon cycle and $\delta^{13} \mathrm{C}$ of bulk marine carbonates. Global and Planetary Change 86-87, 92-100.

Suchéras-Marx, B., Giraud, F., Fernandez, V., Pittet, B., Lécuyer, C., Olivero, D., Mattioli, E., 2013. Duration of the Early Bajocian and the associated $\delta^{13} \mathrm{C}$ positive excursion based on cyclostratigraphy. Journal of the Geological Society, London 170, 107-118.

Voigt, S., Erbacher, J., Mutterlose, J., Weiss, W., Westerhold, T., Wiese, F., Wilmsen, M., Wonik, T., 2008. The Cenomanian - Turonian of the Wunstorf section - (North Germany): global stratigraphic reference section and new orbital time scale for Oceanic Anoxic Event 2. Newsletters on Stratigraphy 43(1), 65-89.

Westbroek, P., Brown, C. W., van Bleijswijk, J., Brownlee, C., Brummer, G. J., Conte, M., Egge, J., Fernández, E., Jordan, R., Knappertsbusch, M., Stefels, J., Veldhuis, M., van der Wal, P., Young, J., 1993. A model system approach to biological climate forcing. The example of Emiliania huxleyi. Global and Planetary Change 8, 27-46. 